\title{
Decreased summer drought affects plant productivity and soil carbon dynamics in a Mediterranean woodland
}

\author{
M. F. Cotrufo ${ }^{1}$, G. Alberti ${ }^{2}$, I. Inglima ${ }^{3}$, H. Marjanović ${ }^{4}$, D. LeCain ${ }^{5}$, A. Zaldei ${ }^{6}$, A. Peressotti ${ }^{2}$, and F. Miglietta ${ }^{6,7}$ \\ ${ }^{1}$ Department of Soil and Crop Science, Colorado State University, Fort Collins, Colorado, USA \\ ${ }^{2}$ Department of Agriculture and Environmental Sciences, University of Udine, Udine, Italy \\ ${ }^{3}$ Department of Environmental Science, Second University of Naples, Caserta, Italy \\ ${ }^{4}$ Croatian Forest Research Institute, Jastrebarsko, Croatia \\ ${ }^{5}$ USDA-ARS, RRRU Crops Research Laboratory, Fort Collins, Colorado, USA \\ ${ }^{6}$ CNR-IBIMET, Firenze, Italy \\ ${ }^{7}$ FoxLab, E.Mach Foundation, IASMA, San Michele all'Adige, Trento, Italy
}

Received: 30 May 2011 - Published in Biogeosciences Discuss.: 28 June 2011

Revised: 7 September 2011 - Accepted: 20 September 2011 - Published: 27 September 2011

\begin{abstract}
Precipitation patterns are expected to change in the Mediterranean region within the next decades, with projected decreases in total rainfall and increases in extreme events. We manipulated precipitation patterns in a Mediterranean woodland, dominated by Arbutus unedo L., to study the effects of changing precipitation regimes on aboveground net primary production (ANPP) and soil C dynamics, specifically plant-derived $\mathrm{C}$ input to soil and soil respiration (SR). Experimental plots were exposed to either a $20 \%$ reduction of throughfall or to water addition targeted at maintaining soil water content above a minimum of $10 \%$ $\mathrm{v} / \mathrm{v}$. Treatments were compared to control plots which received ambient precipitation. Enhanced soil moisture during summer months highly stimulated annual stem primary production, litter fall, SR and net annual plant-derived $\mathrm{C}$ input to soil which on average increased by $130 \%, 26 \%, 58 \%$ and $220 \%$, respectively, as compared to the control. In contrast, the $20 \%$ reduction in throughfall (equivalent to $10 \%$ reduction in precipitation) did not significantly change soil moisture at the site, and therefore did not significantly affect ANPP or SR. We conclude that minor changes (around $10 \%$ reduction) in precipitation amount are not likely to significantly affect ANPP or soil $\mathrm{C}$ dynamics in Mediterranean woodlands. However, if summer rain increases, $\mathrm{C}$ cycling will significantly accelerate but soil C stocks are not likely to be changed in the short-term. More studies involving modelling of long-term $\mathrm{C}$ dynamics are needed to predict if the
\end{abstract}

Correspondence to: M. F. Cotrufo (francesca.cotrufo@colostate.edu) estimated increases in soil $\mathrm{C}$ input under wet conditions is going to be sustained and if labile $\mathrm{C}$ is being substituted to stable $\mathrm{C}$, with a negative effect on long-term soil C stocks.

\section{Introduction}

Terrestrial ecosystems globally are currently a net sink of C although with a high inter-annual variability (Canadell et al., 2007; Ciais et al., 2005). This means that net primary production rates are, on a global average, exceeding decomposition rates and ecosystems are sequestering $\mathrm{C}$ from the atmosphere. The extent to which this imbalance may persist in the future will depend on factors controlling production and decomposition and how they will be affected by land use and climate change (Zhao and Running, 2010).

At Mediterranean latitudes, mean annual temperature and potential evapotranspiration have been projected to increase, further exacerbating summer drought stress (IPCC, 2007). During the last three decades, heat waves increased significantly in the Mediterranean basin: the number of hot days tripled, while the number of hot nights quadrupled (Kuglitsch et al., 2010). Temperature and precipitation have been inversely correlated since 1950 with increasing temperature and decreasing precipitation trends (Camusso et al., 2010). Changes in extreme precipitation, however, may vary regionally and seasonally, with precipitation increasing in the winter in the northern Mediterranean region, while decreasing in the southern region and over summer, with the exception of some localized areas (Gao et al., 2006). Although it is not clear if and how long this coupling will persist, and if

Published by Copernicus Publications on behalf of the European Geosciences Union. 
the predicted changes in precipitation (Gao et al., 2006) will occur, climate change is likely to significantly alter the $\mathrm{C}$ balance of Mediterranean ecosystems (Ciais et al., 2005).

This justifies increasing efforts to understand the effects of changing precipitation regimes on ecosystems, and several experiments using water manipulation (e.g. Beier et al., 2004; Knapp et al., 2002; Gundersen et al., 1998; Johnson et al., 1998; Brando et al., 2008) or natural precipitation gradients (e.g. Tipping et al., 1999; Talmon et al., 2011) have been performed in different terrestrial ecosystems. Rainfall manipulations have only recently been attempted in Mediterranean woodland ecosystems using either drains for throughfall interception (Alberti et al., 2007; Sardans et al., 2008) or large rain exclusion shelters (Misson et al., 2010).

Researching the effects of changing precipitation patterns is challenging for different reasons: it is difficult to predict the overall direction of the expected changes (Gao et al., 2006) and it is even more difficult to predict how seasonal precipitation patterns will be affected and if the frequency of extreme events will change (Schiermeier, 2010). In addition, precipitation changes may directly or indirectly affect many processes in terrestrial ecosystems, increasing the complexity of ecosystem responses to precipitation changes (Heisler and Weltzin, 2006). In Mediterranean forest ecosystems, which are subject to summer water stress and fix most $\mathrm{C}$ during the spring or autumn months, increasing the intensity and duration of summer drought is not likely to affect forest productivity and their annual $\mathrm{C}$ balance (Allard et al., 2008). However, light-saturated leaf photosynthesis increased in Mediterranean forest trees, when soil moisture was experimentally enhanced, during summer months (Ripullone et al., 2009), suggesting that productivity could be enhanced if summer precipitation increases.

While many studies have investigated the effects of precipitation changes on plant productivity and SR, the net results of these two processes, i.e. changes in soil organic C (SOC) stocks, have been largely overlooked. This is not surprising as most ecosystem manipulation experiments have lasted only a few years and tend to focus on processes, such as productivity or respiration, for which changes in process rates are high compared to the size of the rate itself, and where the response to climate drivers is generally fast. In contrast, quantifying changes in SOC stocks after only a few years of experimental manipulation is extremely challenging. Therefore, in short-term manipulation studies, SOC changes may be easier inferred from relative changes in soil $\mathrm{C}$ input and output fluxes. Plant-derived $\mathrm{C}$ input to soil can be quantified by the mass balance approach (Balesdent and Balbane, 1992), using the differences in the stable $C$ isotope composition of native SOC and new plant-derived organic matter. When natural isotope abundances do not allow the use of this approach, distinct $\mathrm{C}$ isotope signatures in the SOC pool and plant-derived organic matter can be realized, in manipulation experiments, by growing $\mathrm{C}_{3}$ plants (characterized by a $\delta^{13} \mathrm{C}$ on average around $-27 \%$ o) in $\mathrm{C}_{4}$ soils, i.e. soils developed under vegetation dominated by $\mathrm{C}_{4}$ plants (characterized by a $\delta^{13} \mathrm{C}$ on average around $-12 \%$ ), or vice versa. This approach has been successfully applied in pot experiments (Ineson et al., 1996) and field studies (Hoosbeek et al., 2004). In this study, we use this method to estimate in situ net belowground $\mathrm{C}$ input to soils and to assess treatments effects on soil C dynamics.

In the context of climate change, and because of the high uncertainty associated with future precipitation scenarios (IPCC, 2007), our manipulation experiment was designed to generate soil moisture conditions that contrast (i.e. drier fall-winter-spring periods and wetter summers) with those commonly occurring in the Mediterranean region, allowing the study of fundamental controls of soil moisture on plant and soil $\mathrm{C}$ dynamics in this region. Specific aims of this work were to test the following hypotheses: (1) in an evergreen Mediterranean woodland, plant growth and therefore plant-derived $\mathrm{C}$ input to the soil, both from above and belowground are controlled by soil moisture, so a decrease in precipitation throughout the year will result in a significant reduction in soil $\mathrm{C}$ input. In contrast, enhanced water availability during the summer will stimulate NPP and strongly increase soil C input; (2) similarly, total SR in Mediterranean woodland is controlled directly and indirectly (i.e. via increased plant-derived $\mathrm{C}$ input) by the available soil water, thus a decrease in precipitation throughout the year will suppress SR. Soil respiration will instead be enhanced if soil water increases during summer months.

To test the above hypotheses, we measured annual leaf litter fall, stem growth and continuous SR in an evergreen Mediterranean woodland subject to a throughfall manipulation experiment and quantified, by the use of stable $\mathrm{C}$ isotopes, changes in root-derived net $\mathrm{C}$ input to soil as affected by the water manipulation. Additionally, we discuss the implication of the observed treatment effects on soil C fluxes for soil C stocks.

\section{Materials and methods}

\subsection{Study site}

The study site is a Mediterranean evergreen woodland located in Tolfa-Allumiere, in Central Italy not far from the Tyrrhenian coast $\left(42^{\circ} 11^{\prime} \mathrm{N} 11^{\circ} 56^{\prime} \mathrm{E}\right)$, at an elevation of $500 \mathrm{~m}$ a.s.l. At the site, Arbutus unedo L. is the dominant species (65\%), while Erica arborea L. (13\%), Fraxinus ornus L. (8\%), Quercus pubescens Willd. (5\%), and Quercus cerris L. (4\%) are present at lower densities. All plants at the site are $\mathrm{C}_{3}$. Arbutus unedo $\mathrm{L}$. mean canopy height is $5 \mathrm{~m}$ and stem density averages 4070 stems ha $^{-1}$. The climate is typical Mediterranean, with a long-term mean (1980-2010) annual precipitation of $729 \mathrm{~mm}$ and a mean annual air temperature of $13^{\circ} \mathrm{C}$. The soil is classified as an Andisol according to the USDA system, and has an average depth of $31 \mathrm{~cm}$; 
Table 1. Amounts and timing of water additions to the wet treatment by irrigation, and total water input (i.e., irrigation + rainfall) for the growing season (March to September), for the five years of the water manipulation experiment. For comparison, annual rainfall, rainfall during the growing season and long term means (LTM, 1980-2010) are also provided.

\begin{tabular}{lcccccc}
\hline Year & $\begin{array}{c}\text { Annual } \\
\text { rainfall }\end{array}$ & $\begin{array}{c}\text { Growing } \\
\text { Season } \\
\text { rainfall }\end{array}$ & Irrigation & $\begin{array}{c}\text { Growing } \\
\text { Season total } \\
\text { water input }\end{array}$ & $\begin{array}{c}\text { Irrigation } \\
\text { start date }\end{array}$ & $\begin{array}{c}\text { Irrigation } \\
\text { end date }\end{array}$ \\
\cline { 2 - 5 } & \multicolumn{7}{c}{$(\mathrm{mm})$} & & & \\
\hline 2005 & 935 & 404 & 370 & 774 & $05 / 04$ & $13 / 09$ \\
2006 & 584 & 322 & 352 & 674 & $02 / 07$ & $09 / 08$ \\
$2007^{\#}$ & 383 & 263 & 177 & 440 & $26 / 07$ & $07 / 09$ \\
2008 & 724 & 239 & 533 & 772 & $02 / 07$ & $21 / 08$ \\
2009 & 797 & 218 & 583 & 801 & $22 / 04$ & $27 / 08$ \\
LTM & 729 & 363 & - & - & - & - \\
\hline
\end{tabular}

\# A lightening burned the water pump limiting irrigation performance for the season.

it is acidic $(\mathrm{pH}=4)$, covered by a moder humus, and with low bulk density (BD $=0.49$ and $0.91 \mathrm{~g} \mathrm{~cm}^{-3}$, for the $\mathrm{O}$ and B horizons, respectively) typical of volcanic-derived soils.

\subsection{Throughfall manipulation experiment}

The throughfall manipulation experiment (Alberti et al., $2007)$ included nine $(8 \mathrm{~m} \times 12 \mathrm{~m})$ plots (3 Control, 3 Dry, $3 \mathrm{Wet}$ ) arranged in a randomized block design (i.e. 3 blocks of 3 treatments). Treatments plots were installed in April 2004 and control plots in April 2006. The water manipulation consisted of the following treatments: (1) a control treatment with ambient rainfall, (2) a dry treatment with an exclusion of $20 \%$ of year-round throughfall, and (3) a wet treatment with periodic summer irrigation performed by suspended sprinklers to maintain the soil water content constantly above $10 \% \mathrm{v} / \mathrm{v}$, which is the threshold value for plant water stress at the site (Ripullone et al., 2009). The water used for irrigation was extracted from a well excavated at the site for the purpose of this study ( $70 \mathrm{~m}$ depth). Each irrigation event lasted 3 to $4 \mathrm{~h}$, when water was added at a rate of $15-20 \mathrm{~mm} \mathrm{~h}^{-1}$. Details on irrigation events and total amounts of water added are reported in Table 1. Every year, during the growing season, the wet treatment received on average $755 \pm 55 \mathrm{~mm}$, with the exception of 2007, when lightening destroyed the electric pump used to extract water from the well and this strongly limited the irrigation performance for that year.

For the dry treatment, $20 \mathrm{~cm}$-wide opaque drains placed $80 \mathrm{~cm}$ a part, were suspended below the canopy (i.e. at $1.8 \mathrm{~m}$ above the forest floor), but with a gentle slope towards the edge of the plot, where water flowed into a transversal drain that collected the water to transport it away from the plot area.

In each plot, soil temperature was monitored using 6 copper-constant thermocouples; 3 sensors were positioned at $2 \mathrm{~cm}$ depth to measure temperature in the organic horizon, and 3 sensors were positioned at $12 \mathrm{~cm}$ depth to measure temperature in the mineral horizon. In each plot, soil water content was measured continuously by time-domain reflectometry, with two CS616-L probes connected to a CR10X data logger (Campbell Scientific, INC, Logan, UT, USA). The probes consisted of two $30 \mathrm{~cm}$ long stainless steel rods inserted vertically into the soil. In addition, a weather station was set-up near the experimental site to measure air temperature and air humidity (HMP45AC, Vaisala), incoming solar radiation (CMP3, Kipp and Zonen), wind speed and direction (03002-L, Campbell scientific) and rainfall (Davis pluviometer). All variables were measured at 10 seconds interval $(0.1 \mathrm{~Hz})$ and then averaged to a half-hourly time step using a Campbell Scientific CR10X datalogger

\subsection{Leaf litter fall and tree growth}

Leaf litterfall was measured using litter traps. Three litter traps were randomly installed in each of the plots at a minimum of $2 \mathrm{~m}$ from the border, and left in the same position for the duration of the experiment. Traps were made of a PVC net (mesh size of less than $1 \mathrm{~mm}$ ) in a cone shape and supported by an iron stand with a diameter of $30 \mathrm{~cm}$ and a height of $50 \mathrm{~cm}$. From 2004 to 2009, traps were periodically emptied and litter was stored in plastic bags for transportation to the lab. At the lab, the plant material was sorted by species (i.e., A. unedo vs. others) and litter types (i.e. twigs, leaves etc.), dried at $70^{\circ} \mathrm{C}$ for $48 \mathrm{~h}$ and dry mass determined when it reached a constant weight. A. unedo leaf litter contributed more than $80 \%$ of the total standing litter at the site (data not shown) therefore, litter production data are reported as means of annual A. unedo leaf litter production for each of the experimental treatments.

For the determination of tree growth nine manual dendrometer bands in each of the nine experimental plots were installed on dominant A. unedo trees in April 2009 and measured on September 2009 and again on April 2010. Due to technical limits for the use of dendrometer bands, these were installed only on trees with a diameter at breast height (d.b.h.) greater than $5 \mathrm{~cm}$ (Keeland and Young, 2006). Additional 64 dendrometers were installed on trees outside of the experimental plots to derive specific allometric relationships for A. unedo. Stem biomass was calculated using d.b.h., total stem density at the plot and the allometric relationships. Stem (including branches) primary production (SPP) was then estimated at plot level using percentage increment measured on the selected trees.

\subsection{Soil cores for determination of net annual $C$ input}

Soil was collected from the USDA-ARS Central Plains Experimental Range located in NE Colorado, USA $\left(40^{\circ} 49^{\prime} \mathrm{N}\right.$, 
Table 2. Texture and nutrient content of the native soil (C3 soil) and of the soil used for determination of net annual $\mathrm{C}$ input (C4 soil).

\begin{tabular}{lll}
\hline & C3 soil & C4 soil \\
\hline Sand (\%) & 45 & 70 \\
Silt $(\%)$ & 48 & 12.5 \\
Clay $(\%)$ & 6 & 17.5 \\
$\mathrm{~N}(\mathrm{~g} / \mathrm{Kg})$ & 3.9 & 1.37 \\
Total P $(\mathrm{g} / \mathrm{Kg})$ & n.d. & 0.5 \\
\hline
\end{tabular}

$104^{\circ} 46^{\prime} \mathrm{W}$ ), classified as a Zigweid soil series (Fine-loamy, mixed, superactive, mesic Ustic Haplocambids), with a $\mathrm{pH}$ of 7.4. At the site plant cover of $\mathrm{C}_{4}$ grasses is approximately $75 \%$, primarily Bouteloua gracilis Willd. Ex Kunth. Above-ground plant shoots and crowns were scraped off with a front-loading tractor; then soil was excavated from the approximately $3-30 \mathrm{~cm}$ depth and screened to remove large roots with at $1 \mathrm{~cm}$ sieve. Soil was air-dried prior to being sealed and boxed for shipment to Italy. This soil is refereed as to " $\mathrm{C}_{4}$ soil". Upon arrival to Italy, the $\mathrm{C}_{4}$ soil was ground and sieved to $2 \mathrm{~mm}$ and well mixed to make a homogeneous soil pool, before using it for ingrowth cores and chemical analyses $\left(\mathrm{C} \%\right.$ and $\left.\delta^{13} \mathrm{C}\right)$ as described below.

Soil cores, with a diameter of $4 \mathrm{~cm}$ and a height of $30 \mathrm{~cm}$, were made of a $2 \mathrm{~mm}$ mesh net (thus allowing the entry of fine roots), and filled with the $\mathrm{C}_{4}$ soil to a $\mathrm{BD}$ of $0.61 \mathrm{~g} \mathrm{~cm}^{-3}$, calculated as the average BD across the $0-30 \mathrm{~cm}$ soil profile at the study site. Texture and nutrients content for the $\mathrm{C}_{4}$ soil and for the native soil $\left(\mathrm{C}_{3}\right.$ soil $)$ are reported in Table 2. In October of 2007, three replicate cores were inserted randomly within each of the experimental plots, and the net at the top of each core closed to avoid above-ground litter input. Cores were sampled a year later, and soils from each core separated into $0-15 \mathrm{~cm}$ and $15-30 \mathrm{~cm}$ depths. All soil samples were sieved to $2 \mathrm{~mm}$ with root samples carefully removed and washed with demineralized water. Both, soil and root samples, were dried in an oven at $70^{\circ} \mathrm{C}$, pulverized and analyzed for $\% \mathrm{C}$ and $\delta^{13} \mathrm{C}$ by an elemental analyzer (Flash EA $1112 \mathrm{NC}, \mathrm{CE}$ Instrument, Wingan, UK) connected to an Isotope Ratio Mass Spectrometer (IRMS, Delta Plus, ThermoFinnigan, Bremen, Germany). Prior to $\mathrm{C}$ analyses all soil samples were fumigated with $\mathrm{HCl}$ (Harris et al., 2000), to eliminate carbonates.

We report $\mathrm{C}$ isotope values in the delta notation, where, relative to the international standard (VPDB), $R_{\text {sample }}$ and $R_{\text {standard }}$ are the molar fractions of ${ }^{13} \mathrm{C} /{ }^{12} \mathrm{C}$ for the sample and the standard, respectively. The standard deviation for the repeated analysis of an internal standard (commercial cellulose) was better than $0.1 \%$. The calibration versus VPDB was done by measurement of IAEA USGS-24 (graphite) and IAEA-CH7 (polyethylene).

The measured $\delta^{13} \mathrm{C}$ values were used to calculate the proportion of new $C\left(f_{\text {new }}\right.$, i.e. the net annual below-ground $C$ input), by using the following mass balance equation (Del Galdo et al., 2003):

$\left[f_{\text {new }}=\frac{\delta_{\text {soil }}-\delta_{\text {old }}}{\delta_{\text {veg }}-\delta_{\text {old }}}\right]$

where $\delta_{\text {soil }}$ is the $\delta^{13} \mathrm{C}$ of the organic matter of the $\mathrm{C}_{4}$ soil collected from each soil core after one year of field incubation, $\delta_{\text {old }}$ is the $\delta^{13} \mathrm{C}$ of the organic matter of the $\mathrm{C}_{4}$ soil measured before incubation $\left(-17.22 \%\right.$ ) and $\delta_{\text {veg }}$ is the $\delta^{13} \mathrm{C}$ of the roots from the same soil core (which overall averaged $-28.42 \%$ o). Knowing the $f$ values for the new $C$, organic $\mathrm{C}$ concentrations and soil $\mathrm{BD}$, amounts $\left(\mathrm{g} \mathrm{m}^{-2}\right)$ of the net plant-derived $\mathrm{C}$ input $\left(\mathrm{C}_{\text {new }}\right)$ were obtained for all soil samples.

\subsection{Soil respiration}

Continuous SR was measured every two hours using three automated SR systems. A detailed description of the system is reported in Delle Vedove et al. (2007). Briefly, each system was a closed dynamic system according to Livingston and Hutchinson (1995) and operated six automated SR chambers. Each chamber consisted of a steel collar $(15 \mathrm{~cm}$ of diameter and $8 \mathrm{~cm}$ height) and a motor closing steel lid. This is positioned to be on the north side of the collar when open in vertical position, to avoid shading the chamber. During the operation, air was circulated between the soil chamber and the infrared gas analyzer (IRGA, SBA-4, PP-System), at a constant flow rate $\left(0.5 \mathrm{~L} \mathrm{~min}^{-1}\right)$. The rate of increase of $\mathrm{CO}_{2}$ concentration within each chamber was used to estimate, the soil $\mathrm{CO}_{2}$ efflux rate $\left(\mu \mathrm{mol} \mathrm{m}{ }^{-2} \mathrm{~s}^{-1}\right)$ by an empirical diffusion model (Delle Vedove et al., 2007).

At each plot, six PVC collars $(8 \mathrm{~cm}$ height and $15 \mathrm{~cm}$ diameter) were installed randomly in the middle of the plot at around $1.5 \mathrm{~m}$ from each other, in order to avoid confounding border and drain effects. At any given time, the three systems were placed within the same block, with one system per plot. The systems were moved from one block to the next, in general, every two weeks. In order to estimate annual mean flux and related uncertainty, SR measurements at each plot (SR) were gap-filled using the model proposed by Davidson et al. (1998), based on the continuous measurements of soil water content and soil temperature taken at the plot throughout the year:

$\left[\mathrm{SR}=\beta_{0} e^{\beta_{1} T} a e^{b \mathrm{MP}}\right]$

where $T$ is soil temperature $\left({ }^{\circ} \mathrm{C}\right)$, MP is the soil matrix potential estimated using soil water content measurements and soil texture (Saxton et al., 1986), $\beta_{0}, \beta_{1}, a$ and $b$ are fitting coefficients. When soil water content is so low that desiccation stress of roots or microorganisms is possible, matrix potential is a more appropriate expression of soil moisture than either volumetric or gravimetric water content (Davidson et al. 1998). 
Additionally, for the wet treatment, we calculated the specific water addition stimulation effect for the 2008 and 2009, by dividing the difference between the soil $\mathrm{C}$ efflux $\left(\mathrm{g} \mathrm{C} \mathrm{m}^{-2} \mathrm{yr}^{-1}\right)$ in the wet and control treatments by the $\mathrm{mm}$ of water added for irrigation.

\subsection{Data analysis}

Differences among years and treatments were assessed through analysis of variance (ANOVA) performed using SAS 9.1 (SAS Institute Inc., Cary, NC, USA) using the GLM procedure. Variables were transformed (either square root or logarithm) when normality was violated (Shapiro-Wilk test). A one-way ANOVA was used to test differences among treatments when data were available for one year only (i.e. ANPP and soil $\mathrm{C}$ input), while two-way ANOVA was used to test differences among treatments and years in the other cases (i.e. SWC, SR and litter fall). For data in the period 20052007, wet and dry treatments were compared, because of lack of control data. Thereafter, for all variables and years, dry, control, and wet treatments were compared. Significant treatment effects $(p<0.05)$ were further explored via a posteriori treatment comparison using the Least-Squares means test with Tukey adjustment for multiple comparisons. Differences in litter input were regressed against differences in water input ( $\left.\Delta_{\text {waterinput }}\right)$ using SigmaPlot v. 11 (@Systat Softwar Inc.). $\Delta_{\text {waterinput }}$ was calculated, using average values $(n=3)$, as: (i) for Wet-Dry, irrigation $+20 \%$ throughfall precipitation; (ii) for Wet-Control, irrigation only; (iii) for Control-Dry, $-20 \%$ throughfall precipitation.

\section{Results}

\subsection{Climate}

Averaging across the five years of the study, mean annual air temperature at the experimental site was $15.5^{\circ} \mathrm{C}$ and annual precipitation was $686 \mathrm{~mm}$ (Fig. 1, Table 1). Air temperature followed the typical Mediterranean patterns, with mild winter $\left(9^{\circ} \mathrm{C}\right)$ and warm summer months $\left(23.2^{\circ} \mathrm{C}\right)$. Similarly, rain events were unevenly distributed throughout the year, with a maximum during autumn and winter (249 and $252 \mathrm{~mm}$, respectively) and a minimum during spring and summer (113 and $112 \mathrm{~mm}$, respectively). 2007 was the driest year $(383 \mathrm{~mm})$, while 2005 was the wettest year $(935 \mathrm{~mm})$.

Soil water content followed the seasonality of temperature and precipitation with lower values during summer months and, across the entire study period, it was higher in the wet treatment (Fig. 1). In particular, as a result of the experimental manipulation, during years when all treatments data were available (2007-2009), soil water content was on average significantly higher in the wet plots than in the control plots, especially during summer months ( $p=0.04$; Fig. 1$)$, while no significant difference was found between control and dry treatments. 2008 and 2009, were the two years when
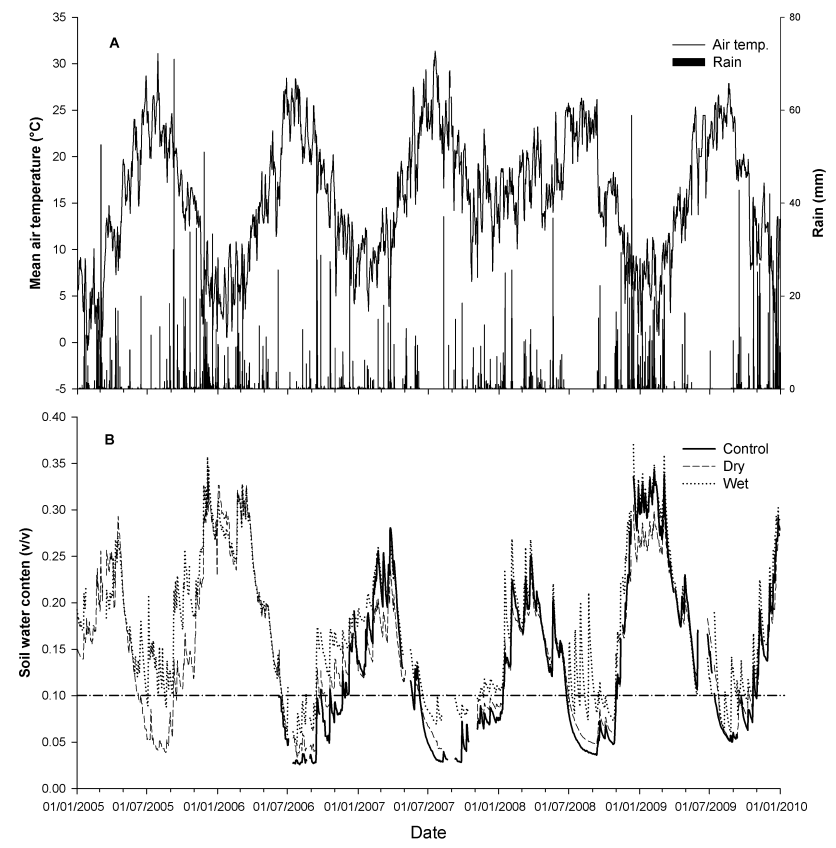

Fig. 1. Daily mean air temperature and precipitation events recorded by the meteorological station at the site from 2005 to 2010 (a). Soil water content measured in the control, dry and wet plots, from 2005 to 2010 (b).

we achieved the best irrigation performance and continuous SR data. These two years had similar annual rainfall (724 and $797 \mathrm{~mm}$, respectively) but contrasting rainfall distribution, with 2008 having a relative dry summer $(47 \mathrm{~mm})$ while 2009 had a relative wet summer (102 mm), and consequently contrasting soil moisture (Fig. 1). As a result of varied precipitation patterns, the treatments effect on soil moisture differed between 2008 and 2009, with a notable increase in soil water content for the wet treatment in summer 2008, as compared to the control and dry, and less difference in soil water content among treatments in 2009 (Fig. 1).

\subsection{Leaf litter fall and tree growth}

Statistical analysis did not show any significant difference in terms of standing biomass, species composition and litter production between blocks prior to the manipulation (data not shown). At a year by year analysis, higher annual leaf litter production was observed in the wet plots as compared to the dry in 2008 and 2009, but neither of the treatments significantly differed from the control (Table 3 ). However, across 2008 and 2009, wet plots produced $26 \%$ more litter than control, and across all the experimental period (20042009), wet treatment produced $41 \%$ more litter than dry. Most interestingly, when relative differences in leaf litter fall between treatments were regressed against relative differences in annual water input for the same two treatments a significant direct linear correlation emerged (Fig. 2), with 


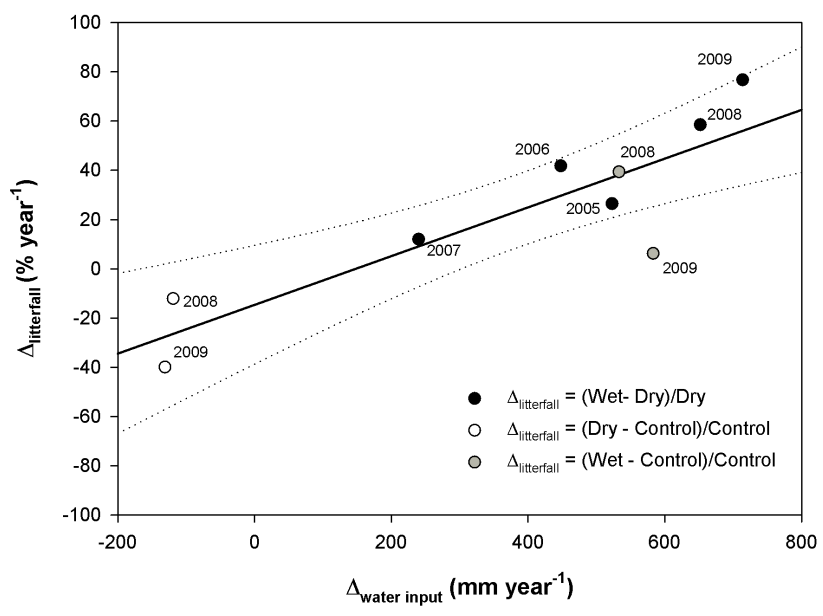

Fig. 2. Litterfall changes $\left(\Delta_{\text {litterfall }}\right)$ vs. corresponding changes in annual water inputs $\left(\Delta_{\text {water input }}\right)$. Dotted lines represent $95 \%$ confidence intervals. Regression line is: $\Delta_{\text {litter }}=0.10^{*} \Delta_{\text {water input }}$ -14613 . $R^{2}=0.76, p=0.002$. Intercept is not significantly different from $0(p=0.195)$.

Table 3. Litterfall production $\left(\mathrm{g} \mathrm{m}^{-2} \mathrm{yr}^{-1}\right)$ in the control, dry and wet treatments, for the five years of the throughfall manipulation experiment. Values are the means with \pm 1 standard error $(n=3)$. Within the same year, different letters indicate a significant difference among treatments $(p<0.05)$.

\begin{tabular}{c|rl|cc|cc}
\hline & \multicolumn{5}{|c}{ Litterfall production $\left(\mathrm{g} \mathrm{m}^{-2} \mathrm{yr}^{-1}\right)$} \\
\hline Year & Dry & Control & Wet \\
\hline 2005 & $189 \pm 35$ & $a$ & - & - & $239 \pm 31$ & $a$ \\
2006 & $227 \pm 61$ & $a$ & - & - & $322 \pm 31$ & $a$ \\
2007 & $383 \pm 29$ & $a$ & - & - & $429 \pm 66$ & $a$ \\
2008 & $386 \pm 77$ & $a$ & $439 \pm 43$ & $a b$ & $612 \pm 30$ & $b$ \\
2009 & $211 \pm 44$ & $a$ & $351 \pm 80$ & $a b$ & $373 \pm 27$ & $b$ \\
\hline
\end{tabular}

a $10 \%$ increase in litter fall for every $100 \mathrm{~mm}$ addition in annual water input.

Five years after the beginning of the experimental manipulation, annual tree growth and estimated SPP was $117 \pm 62$, $82 \pm 29$ and $190 \pm 13 \mathrm{~g} \mathrm{C} \mathrm{m}^{-2} \mathrm{yr}^{-1}$, for the dry, control and wet treatments, respectively. SPP was more than doubled in the wet treatment as compared to control plots, and this difference was statistically significant. Due to the large variability in the annual growth rate of trees grown in the dry treatment, there were no significant differences between the dry and the other two treatments $(p=0.234)$.
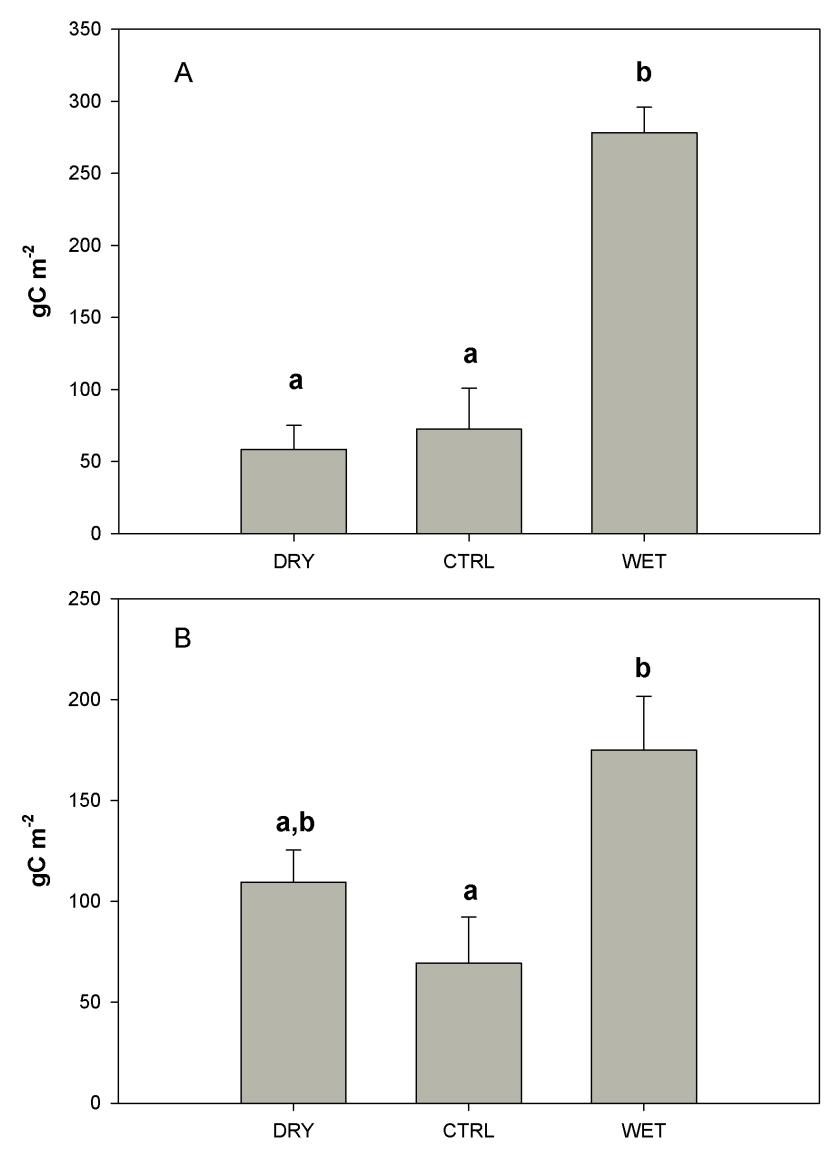

Fig. 3. Net plant-derived SOC, as estimated by the $\mathrm{C}_{4}$ soil cores approach, after one year of incubation in control, dry and wet plots, for (a) the $0-15 \mathrm{~cm}$ and (b) the $15-30 \mathrm{~cm}$ depth layer. Values are means, with bars as standard errors. Different letters indicate a significant difference among treatments $(p<0.05)$.

\subsection{Net annual below-ground $\mathrm{C}$ input to soil}

Estimates of root-derived $\mathrm{C}$ input were obtained by the stable $\mathrm{C}$ isotope approach and rely on the assumption that root inputs are the same inside and outside of the in-growth bags and are independent of soil properties. The net annual rootderived $\mathrm{C}$ input varied from 58 to $278 \mathrm{~g} \mathrm{C} \mathrm{m}^{-2}$ and from 69 to $175 \mathrm{~g} \mathrm{C} \mathrm{m}^{-2}$ in the $0-15$ and $15-30 \mathrm{~cm}$, respectively. In both horizons, root $\mathrm{C}$ input was significantly larger $(p<0.0001)$ in the wet treatment than in the dry and control treatments, which did not differ from one another (Fig. 3). On average in the wet plots, net annual root-derived $\mathrm{C}$ input was $220 \%$ higher than in control plots.

\subsection{Soil respiration}

We experienced several problems with SR measurements in the initial years of the experiment due to equipment failure and adverse weather events, including lightning in 2007 which burned-out the SR system; therefore we report here 

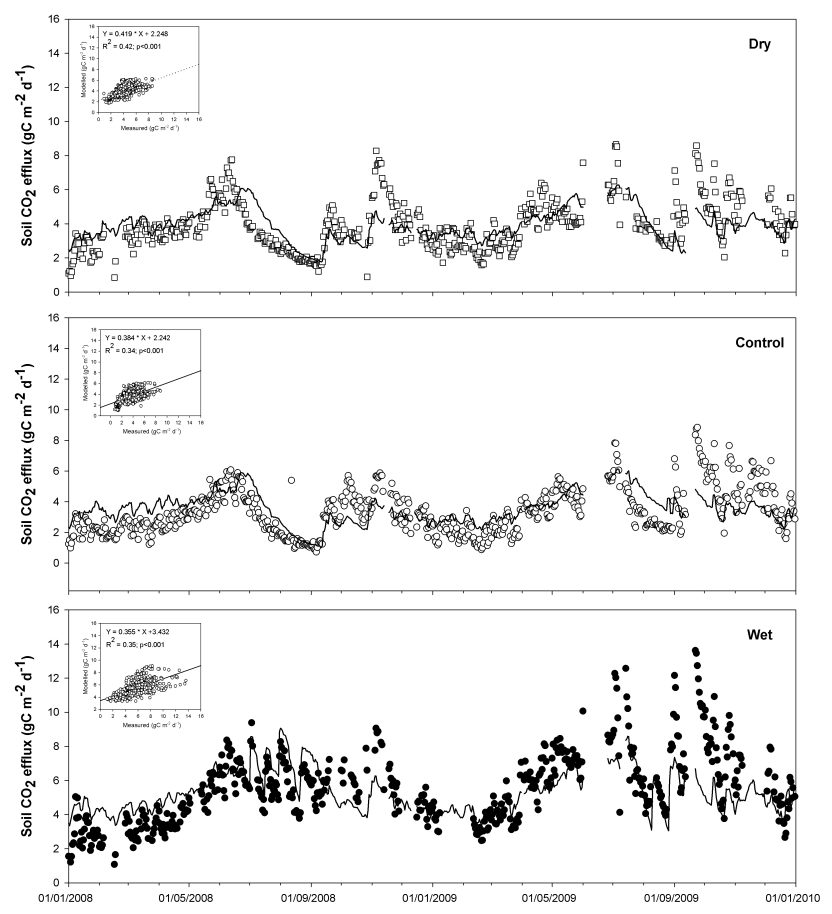

Fig. 4. Continuously measured (open symbols) and modelled (line) daily soil respiration for 2008 and 2009, in the (a) dry, (b) control and (c) wet plots. Correlation between modelled and measured data are reported for each treatment in a top left panel.

only the data for 2008 and 2009 (Fig. 4) when good yearround measurements were obtained. For the dry and control plots, in 2008, SR increased progressively from the winter to the spring as a result of increasing temperature, but decreased thereafter to reach a minimum by the end of summer as a result of summer water stress. SR increased again in the fall responding to increasing soil moisture (Fig. 4). In 2009, the seasonal variability was much less pronounced, most likely as a result of wetter conditions. No significant differences in SR were recorded in either 2008 or 2009 between the control and dry treatment $(p=0.12$ and $p=0.09$, respectively; Fig. 5). By contrast, SR was significantly increased in the wet plots both in 2008 ( $p=0.002$ and $p=0.013$ in comparison to control and dry plots, respectively) and 2009 ( $p<0.001$ and $p=0.006$ in comparison to control and dry plots, respectively; Fig. 5). When normalized to $\mathrm{mm}$ of water added through irrigation, the irrigation enhancement effect on soil respiration, with respect to control, was 1.37 and $1.06 \mathrm{~g} \mathrm{C} \mathrm{m}^{-2} \mathrm{yr}^{-1} \mathrm{~mm}^{-1}$ in 2008 and 2009, respectively. Additionally, in the wet plots, the seasonal SR dynamics were smoother and appeared to follow more the dynamics of temperature than soil moisture (Figs. 1 and 3).

\subsection{Treatment effects on $\mathrm{C}$ fluxes}

In summary at our study site, a $20 \%$ reduction of annual throughfall appeared not to affect significantly either litterfall

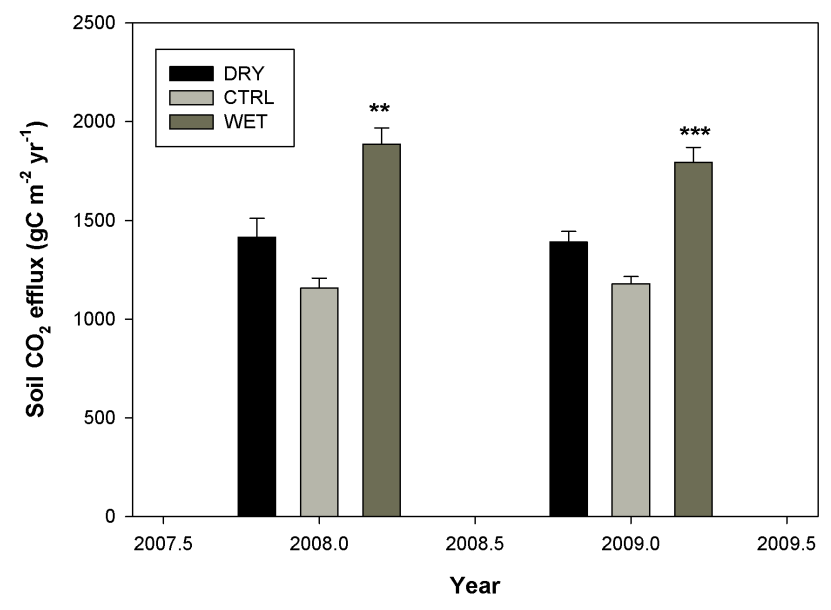

Fig. 5. Cumulative annual soil respiration in the control, dry and wet plots for the 2008 and 2009. Data are means $(n=3)$ with bars as standard error. $* *=P<0.01 ; * * *=P<0.001$.

or SPP or below-ground C input or soil respiration. In contrast, increased soil water content during summer months above $10 \% \mathrm{v} / \mathrm{v}$ strongly stimulated $\mathrm{C}$ fluxes at the site, with a significant $130 \%$ increase in SPP, $26 \%$ increase in litterfall, and $58 \%$ stimulation of SR, with respect to values measured in the control treatment. The proportionally higher increase in productivity than in SR might have been the cause for the observed significant increase in net soil $\mathrm{C}$ input, which was stimulated by $220 \%$ compared to the control.

In terms of actual soil $\mathrm{C}$ fluxes, combining mean litterfall values with root derived $\mathrm{C}$ input to soil in 2008, the only year when we have data for root-derived $\mathrm{C}$ input to soil, the estimated mean net $\mathrm{C}$ input to soil was 349,351 and $759 \mathrm{~g} \mathrm{C} \mathrm{m}^{-2} \mathrm{yr}^{-1}$, for the control, dry and wet treatments, respectively, and considering both leaf litter and roots inputs. For the same year total soil C output from SR was 1157, 1415 and $1887 \mathrm{~g} \mathrm{C} \mathrm{m}^{-2} \mathrm{yr}^{-1}$, for the control, dry and wet treatments, respectively. Whereas soil $\mathrm{C}$ fluxes between the dry and control treatments did not statistically differ, in the wet treatment net soil $\mathrm{C}$ input exceeded the control by an average of $410 \mathrm{~g} \mathrm{C} \mathrm{m}^{-2} \mathrm{yr}^{-1}$. Similarly, total soil C output in the wet treatment exceeded the output measured in the control treatment by $730 \mathrm{~g} \mathrm{C} \mathrm{m}^{-2} \mathrm{yr}^{-1}$ on average while there were no significant differences between the dry and the control treatments.

\section{Discussion}

At our evergreen Mediterranean woodland, because of the large contribution of stem-flow (about $50 \%$ of total interception) to water reaching the soil in A. unedo stands (Bellot and Escarre, 1998), the $20 \%$ exclusion of throughfall (from the troughs suspended below the canopy) only acted on ca. one-half of the incident precipitation, giving only a $10 \%$ 
difference in water input between the control and dry treatment. Furthermore, in this Mediterranean region, much of the precipitation during the wettest part of the year (spring and autumn) occurs as intense rainfall events with significant surface runoff. Thus, the difference between dry and control treatments in the amount of water that infiltrates (and thus impacts soil moisture) is likely much further reduced. Other potential explanations, such as lateral water flow into the dry treatment plots or hydraulic lift, appear unlikely. Soil moisture levels rarely reach field capacity, even in the irrigated treatments (Fig. 1b), soils are shallow $(31 \mathrm{~cm})$ and the ground water table is deep (ca. $70 \mathrm{~m}$ ). Moreover, the A. unedo trees are relatively small, with an average height of $5 \mathrm{~m}$, and all our measurements were taken in the inner part of each plot $(8 \times 12 \mathrm{~m})$, in order to exclude border effects.

In 2008 and 2009, mean annual leaf litter production was consistently less in the dry plots as compared to wet and control plots (Table 3). However, due to the high spatial variability, the difference was not significant. Across all three treatments, differences in mean leaf litter fall among treatments were highly correlated with differences in annual water input, with an additional $10 \%$ leaf litter fall every additional $100 \mathrm{~mm}$ of rainfall a year (Fig. 2). Contrasting litter fall results have been reported from other water manipulation studies in relatively wetter systems, where throughfall was reduced by a larger extent than at our study site. A throughfall reduction of $70 \%$, corresponding to a rainfall reduction of $34-40 \%$, significantly reduced soil water content and, consequently, ANPP in an evergreen forest in the Amazon basin that receives an annual precipitation of 1700 to $3000 \mathrm{~mm}$, but also characterized by a six month dry season (Brando et al., 2008). At that site, litterfall responded much less than ANPP to the imposed drought stress and in only one of the seven years of the experimental manipulation was significantly reduced with respect to the control. By contrast, a throughfall reduction of $33 \%$ applied to a temperate deciduous forest in Tennessee, which receives a mean annual precipitation of $1358 \mathrm{~mm}$, significantly increased annual leaf litterfall under the dry treatment compared to the wet treatment (Froberg et al., 2008; Hanson et al., 2003). The authors explained this finding as the result of reduced nutrient availability, with higher nitrogen leaching, under the wet treatment (Johnson et al., 2008). In our ecosystem, nitrate production is inhibited as a result of allelopathic reactions (Castaldi et al., 2009) and plants uptake $\mathrm{N}$ primarily as ammonium, which is less mobile than nitrate.

While the reduced precipitation input at our study site did not appear to modify below-ground $\mathrm{C}$ cycling, with similar rates of net root-derived $\mathrm{C}$ input and soil respiration measured in the dry and control treatments, it started to reduce leaf litter input (Table 3). A decline in leaf level C-uptake in the dry treatment has been previously reported (Ripullone et al., 2009). Additionally, at our study site, throughfall displacement significantly slowed down above-ground litter decomposition, as compared to the control (Cotrufo et al.,
2010). Litter decomposition is a process that depends on the moisture level of the litter layer (Anderson, 1991) which, contrary to the moisture level of the soil profile, was significantly affected by the $20 \%$ throughfall exclusion (data not shown). This reduction in litter decomposition did not translate into similar reduction in soil respiration, despite the fact that we did not exclude the litter layer from our chambers. This apparent discrepancy may be explained by a relatively small contribution of the leaf litter decomposition to soil respiration at the site.

As expected, increased soil moisture during the summer months to above $10 \% \mathrm{v} / \mathrm{v}$, specified as a soil moisture value at which $A$. unedo trees did not show symptoms of water stress (Ripullone et al., 2009), significantly enhanced SPP, leaf litterfall and SR by $130 \%, 26 \%$, and $58 \%$ respectively, as compared to control values, at our study site. Analyzing 12 years data on ANPP and precipitation at 11 Long Term Ecological Research sites within continental US, Knapp \& Smith (2001), observed that, at continental scale, ANPP was highly correlated with mean annual precipitation and that wet years stimulate ANPP more than dry years inhibit it. Mediterranean ecosystems are typically limited by the availability of water during summer months, and therefore restrict their growth activity to short periods when soil moisture is high, generally in the spring (Allard et al., 2008). However, Mediterranean evergreen forests exhibit the ability to start the growing season as soon as water becomes available, as confirmed by the observation of false ring formation in A. unedo trees triggered by drought (Copenheaver et al., 2010).

Soil water content often limits soil respiration in Mediterranean regions, but its influence on soil $\mathrm{CO}_{2}$ efflux is variable depending on factors such as ecosystem type, soil physicalchemical characteristics, and especially on the degree of dryness and the duration of the drought period before a wetting event (Reichstein et al., 2002). At our study site volumetric soil water content never reached values above $25 \%$, even during winter months when precipitation is higher and temperature lower. These soil moisture values are well within the range of values when soil moisture is highly related to soil respiration (Del Grosso et al., 2005). Thus, it is not surprising that soil respiration was significantly and highly stimulated by summer irrigation. This stimulation, when normalized to the $\mathrm{mm}$ of water added by irrigation, was higher (i.e. 1.37 vs. $1.06 \mathrm{~g} \mathrm{C} \mathrm{m}^{-2} \mathrm{yr}^{-1} \mathrm{~mm}^{-1}$ ) in 2008 than in 2009 . 2008 was characterised by lower summer precipitation than 2009 (Table 1) confirming that, in Mediterranean ecosystems, soil respiration is stimulated by increasing soil moisture proportionally more at sites (or years) with less precipitation (Talmon et al., 2011). In fact, in such ecosystems, C assimilation at canopy level is usually severely reduced during the dry season, so that fewer assimilates are expected to be transported towards the rhizosphere leading to a reduction in total soil respiration (source limitation of rhizosphere respiration; Reichstein et al., 2002). Furthermore, soil organic matter decomposition is strongly reduced during the 
dry period (Raich and Schlesinger, 1992; Rey et al., 2002). In contrast, when water is not a limiting factor, assimilates can be transported to the rhizosphere and heterotrophic respiration is enhanced (Inglima et al., 2009). Our annual soil respiration estimates are well within ranges reported for other Mediterranean ecosystems (Rey et al., 2002; Tang et al., 2005; Tedeschi et al., 2006).

Consistent with the increase in components of ANPP, net annual below-ground $\mathrm{C}$ input, i.e. the $\mathrm{C}$ input to soil ( 0 $30 \mathrm{~cm}$ ) derived from root exudation and turnover which was not respired back to the atmosphere within a year, was highly enhanced by the summer irrigation treatment with $220 \%$ more "new" $\mathrm{C}$ being recovered in wet treatment than in control treatment (Fig. 3). We cannot determine whether this extra $\mathrm{C}$ is the result of increased exudation per unit root biomass or of increased root biomass and/or turnover. Likely, it resulted from a stimulation of all these processes combined. To our knowledge this is the first study that reports in situ estimate of net plant-derived $\mathrm{C}$ input to soil as affected by soil moisture regimes in a woodland ecosystem. However, our method presents several caveats because we measured root $\mathrm{C}$ input to a soil differing in texture, $\mathrm{pH}$ and nutrient status from the native soil (Table 2).

In an evergreen oak forest in Catalonia, soil $\mathrm{C}$ concentration increased after six years of experimental manipulation of soil water input by a $30 \%$ interception of rainfall and the exclusion of run-off (Sardans et al., 2008). The increased soil $\mathrm{C}$ appeared to result from lower soil organic carbon turnover in the dry treatment as compared to the control treatment. Unfortunately, the authors do not report bulk density values at the site, and we cannot speculate if this change actually resulted in an increase of soil C stocks in the dry treatment. Consistently, lower values of the particulate organic matter fraction were reported in wet plots compared to the dry treatment, after four years of exposure to a multi factorial $\left(\mathrm{CO}_{2} \times\right.$ Temperature $\times$ Soil moisture $)$ manipulation in a old-field community (Garten et al., 2009). Also, higher soil moisture levels increased the rate of $\mathrm{C}$ accrual to soil in a restored grassland over a decadal-period (O'Brien et al., 2010), as the result of both increases in NPP and decreased decomposition rates due to periodic seasonal inundation at their moist site. At our xeric woodland site, SR was also enhanced under the irrigation treatment as compared to the control. Unfortunately we did not partition soil respiration, but in Mediterranean deciduous forests, the percentage contribution of heterotrophic respiration to total soil $\mathrm{CO}_{2}$ efflux was reported to range between 48 and $77 \%$ (Subke et al., 2006). At our site, plant productivity was stimulated relatively more than soil respiration. This finding would suggest that most of the increase in soil respiration observed at the site in wet plots as compared to control was driven by an enhanced belowground $\mathrm{C}$ allocation and root turnover, with a minor contribution from the enhancement of the native soil organic matter decay rate. However, in a parallel study we measured from a $7 \%$ up to a $30 \%$ increase, depending on the method of study, in leaf litter turnover time in the wet plots as compared to the control (Cotrufo et al., 2010). Given the much larger actual soil $\mathrm{C}$ efflux with respect to the soil $\mathrm{C}$ input at our study site, and the relatively high contribution of heterotrophic respiration to total soil $\mathrm{CO}_{2}$ efflux in Mediterranean deciduous forests (Subke et al., 2006), C may be circulating faster in the soil of wet plots as compared to control, with little net effect on the total soil C stocks. Future studies investigating changes in different soil organic $\mathrm{C}$ pools and modelling long-term dynamics might help clarify if the observed changes in $\mathrm{C}$ dynamics at our study site would be sustained and eventually result in soil $\mathrm{C}$ stock changes in the long term.

\section{Conclusions}

Our study demonstrated that $\mathrm{C}$ accrual in Mediterranean woodland is primarily controlled by summer water stress. Contrary to our hypotheses on the responses to decreased precipitation, a $20 \%$ reduction of throughfall, corresponding to a $10 \%$ reduction in total rainfall, did not significantly affect soil water content and $\mathrm{C}$ dynamics either in terms of below-ground $\mathrm{C}$ inputs or soil respiration. On the other hand our hypotheses on the effects of decreased summer drought were confirmed and increased water input during summer months significantly enhanced components of ANPP and below-ground C input at our study sites, while also stimulating soil respiration. Estimates of net soil $\mathrm{C}$ inputs in the wet plots were enhanced by $410 \mathrm{~g} \mathrm{C} \mathrm{m}^{-2} \mathrm{yr}^{-1}$ as compared to control, while total outputs were increased by $730 \mathrm{~g} \mathrm{C} \mathrm{m}^{-2} \mathrm{yr}^{-1}$ relative to the control. Given the fact that about half of the $\mathrm{C}$ outputs may be due to autotrophic respiration, these two fluxes may be balancing out with no net effects on total soil $\mathrm{C}$ stocks. Further study should investigate the long-term effects of changing soil $\mathrm{C}$ dynamics as a result of changing precipitation patterns.

Acknowledgements. We thank Piero Toscano for his technical assistance in the establishment and maintenance of the water manipulation experiment, Maša Zorana Ostrogović and Ivan Balenović for installing dendrometer bends and also to Daniela Piermatteo for installing the litter traps. The work was funded by CARBOITALY (FISR, Italian Ministry of Research and Education), by MIND (Contract n. EVK2-CT-2002-00158) and NITROEUROPE under the EC 6th Framework Program (Contract n. 017841), and by CARBO-EXTREME under the 7th Framework Program (Contract n. 226701) EU projects. Access to the throughfall manipulation experiment of Tolfa-Allumiere to HM was funded by the IMECC Integrated Infrastructure Initiative Project under the 6th Framework Program (Contract n. 026188).

Edited by: R. Ceulemans 


\section{References}

Alberti, G., Inglima, I., Arriga, N., Piermatteo, D., Pecchiari, M., Zaldei, A., Papale, D., Peressotti, A., Valentini, R., Cotrufo, M. F., and Miglietta, F.: Cambiamenti nel regime pluviometrico in ecosistemi mediterranei: il progetto MIND, Forest@, 4, 460468, 2007.

Allard, V., Ourcival, J. M., Rambal, S., Joffre, R., and Rocheteau, A.: Seasonal and annual variation of carbon exchange in an evergreen Mediterranean forest in southern France, Glob. Change Biol., 14, 714-725, doi:10.1111/j.13652486.2008.01539.x, 2008.

Anderson, J. M.: The effects of climate change on decomposition processes in grassland and coniferous forests, Ecol. Appl., 1, 326-347, 1991.

Balesdent, J. and Balbane, M.: Maize root-derived soil organic carbon estimated by natural 13C abudance, Soil Biol. Biochem., 24, 97-101, 1992.

Beier, C., Emmett, B., Gundersen, P., Tietema, A., Penuelas, J., Estiarte, M., Gordon, C., Gorissen, A., Llorens, L., Roda, F., and Williams, D.: Novel approaches to study climate change effects on terrestrial ecosystems in the field: Drought and passive nighttime warming, Ecosystems, 7, 583-597, doi:10.1007/s10021004-0178-8, 2004.

Bellot, J. and Escarre, A.: Stemflow and throughfall determination in a resprouted Mediterranean holm-oak forest, Ann. Sci. For., 55, 847-865, 1998.

Brando, P. M., Nepstad, D. C., Davidson, E. A., Trumbore, S. E., Ray, D., and Camargo, P.: Drought effects on litterfall, wood production and belowground carbon cycling in an Amazon forest: results of a throughfall reduction experiment, Philos. T. R. Soc. B., 363, 1839-1848, 2008.

Camusso, D., Bertolin, C., Diodato, N., Barriendos, M., Dominguez-Castri, F., Cocheo, C., della Valle, A., Garnier, E., and Alcoforado, M. J.: The western Mediterranean climate: how will it respond to global warming ?, Climate Change, 100, 137142,2010

Canadell, J. G., Le Quere, C., Raupach, M. R., Field, C. B., Buitenhuis, E. T., Ciais, P., Conway, T. J., Gillett, N. P., Houghton, R. A., and Marland, G.: Contributions to accelerating atmospheric $\mathrm{CO} 2$ growth from economic activity, carbon intensity, and efficiency of natural sinks, P. Natl. Acad. Sci.USA, 104, 1886618870, 2007.

Castaldi, S., Carfora, A., Fiorentino, A., Natale, A., Messere, A., Miglietta, F., and Cotrufo, M. F.: Inhibition of net nitrification activity in a Mediterranean woodland: possible role of chemicals produced by Arbutus unedo, Plant Soil, 315, 273-283, doi:10.1007/s11104-008-9750-x, 2009.

Ciais, P., Reichstein, M., Viovy, N., Granier, A., Ogee, J., Allard, V., Aubinet, M., Buchmann, N., Bernhofer, C., Carrara, A., Chevallier, F., De Noblet, N., Friend, A. D., Friedlingstein, P., Grunwald, T., Heinesch, B., Keronen, P., Knohl, A., Krinner, G., Loustau, D., Manca, G., Matteucci, G., Miglietta, F., Ourcival, J. M., Papale, D., Pilegaard, K., Rambal, S., Seufert, G., Soussana, J. F., Sanz, M. J., Schulze, E. D., Vesala, T., and Valentini, R.: Europe-wide reduction in primary productivity caused by the heat and drought in 2003, Nature, 437, 529-533, doi:10.1038/nature03972, 2005.

Copenheaver, C. A., Gartner, H., Schafer, I., Vaccari, F. P., and Cherubini, P.: Drought-triggered false ring formation in a Mediterranean shrub, Botany-Botanique, 88, 545-555, doi:10.1139/b10-029, 2010.

Cotrufo, M. F., Ngao, J., Marzaioli, F., and Piermatteo, D.: Intercomparison of methods for qauntifying above-ground leaf litter decomposition rates, Plant Soil, 334, 365-376, 2010.

Davidson, E. A., Belk, E., and Boone, R. D.: Soil water content and temperature as independent or confounded factors controlling soil respiration in a temperate mixed hardwood forest, Glob. Change Biol., 4, 217-227, 1998.

Del Galdo, I., Six, J., Peressotti, A., and Cotrufo, M. F.: Assessing the impact of land-use change on soil $\mathrm{C}$ sequestration in agricultural soils by means of organic matter fractionation and stable $\mathrm{C}$ isotopes, Glob. Change Biol., 9, 1204-1213, 2003.

Del Grosso, S. J., Parton, W. J., Mosier, A. R., Holland, E. A., Pendall, E., Schimel, D. S., and Ojima, D. S.: Modeling soil $\mathrm{CO} 2$ emissions from ecosystems, Biogeochemistry, 73, 71-91, doi:10.1007/s10533-004-0898-z, 2005.

Delle Vedove, G., Alberti , G., Peressotti, A., Inglima, I., Zuliani, M., and Zerbi, G.: Automated monitoring of soil respiration: an improved automatic chamber system, Italian Journal of Agronomy, 2, 377-382, 2007.

Froberg, M., Hanson, P. J., Todd, D. E., and Johnson, D. W.: Evaluation of effects of sustained decadal precipitation manipulations on soil carbon stocks, Biogeochemistry, 89, 151-161, 2008.

Gao, X. J., Pal, J. S., and Giorgi, F.: Projected changes in mean and extreme precipitation over the Mediterranean region from a high resolution double nested RCM simulation, Geophys. Res. Lett., 33, L03706, doi:10.1029/2005g1024954, 2006.

Garten, C. T., Classen, A. T., and Norby, R. J.: Soil moisture surpasses elevated $\mathrm{CO} 2$ and temperature as a control on soil carbon dynamics in a multi-factor climate change experiment, Plant Soil, 319, 85-94, doi:10.1007/s11104-008-9851-6, 2009.

Gundersen, P., Boxman, A. W., Lamersdorf, N., Moldan, F., and Andersen, B. R.: Experimental manipulation of forest ecosystems: lessons from large roof experiments, For. Ecol. Manage., 101, 339-352, 1998.

Hanson, P. J., Todd, D. E., and Joslin, J. D.: Canopy production and decomposition, in: North America temperate deciduous forest responses to changing precipitation regimes, edited by: Hanson, P. J., and Wullschleger, S. D., Ecological Studies, Springer Verlag, New York, 303-315, 2003.

Harris, D., Horwáth, W. R., and van Kessel, C.: Acid fumigation of soils to remove carbonates prior to total organic carbon or Carbon-13 isotopic analysis, Soil Sci. Soc. Am. J., 65, 18531856, 2000.

Heisler, J. L. and Weltzin, J. F.: Variability matters: towards a perspective on the influence of precipitation on terrestrial ecosystems, New Phytol., 172, 189-192, 2006.

Hoosbeek, M. R., Lukac, M., van Dam, D., Godbold, D. L., Velthorst, E. J., Biondi, F. A., Peressotti, A., Cotrufo, M. F., de Angelis, P., and Scarascia-Mugnozza, G.: More new carbon in the mineral soil of a poplar plantation under Free Air Carbon Enrichment (POPFACE): Cause of increased priming effect?, Glob. Biogeochem. Cycle, 18, GB1040, doi:10.1029/2003GB002127, 2004.

Ineson, P., Cotrufo, M. F., Bol, R., Harkness, D. D., and Blum, H.: Quantification of soil carbon inputs under elevated CO2:C-3 plants in a C-4 soil, Plant Soil, 187, 345-350, 1996.

Inglima, I., Alberti, G., Bertolini, T., Vaccari, F. P., Gioli, B., 
Miglietta, F., Cotrufo, M. F., and Peressotti, A.: Precipitation pulses enhance respiration of Mediterranean ecosystems: the balance between organic and inorganic components of increased soil CO2 efflux, Glob. Change Biol., 15, 1289-1301, 2009.

IPCC: Climate Change 2007, the IPCC Fourth Assessment Report IPCC, Geneva, Switzerland, 2007.

Johnson, D. W., Hanson, P. J., Todd, D. E., Susfalk, R. B., and Trettin, C. F.: Precipitation change and soil leaching: Field results and simulations from Walker Branch Watershed, Tennessee, Water Air Soil Poll., 105, 251-262, 1998.

Johnson, D. W., Todd, D. E., and Hanson, P. J.: Effects of throughfall manipulation on soil nutrient status: results of 12 years of sustained wet and dry treatments, Glob. Change Biol., 14, 16611675,2008

Keeland, B. and Young, P.: Construction and installation of dendrometer bands for periodic tree-growth measurements, National Wetlands Research Center, Lafayette, LA, http://www. nwrc.usgs.gov/Dendrometer, last access: September 2011, 2006.

Knapp, A. K., and Smith, M. D.: Variation among biomes in temporal dynamics of aboveground primary production, Science, 291, 481-484, 2001.

Knapp, A. K., Fay, P. A., Blair, J. M., Collins, S. L., Smith, M. D., Carlisle, J. D., Harper, C. W., Danner, B. T., Lett, M. S., and McCarron, J. K.: Rainfall variability, carbon cycling, and plant species diversity in a mesic grassland, Science, 298, 2202-2205, 2002.

Kuglitsch, F. G., Toreti, A., Xoplaki, E., Della-Marta, P. M., Zerefos, C. S., Turkes, M., and Luterbacher, J.: Heat wave changes in the eastern Mediterranean since 1960, Geophys. Res. Lett., 37, L04802, doi:10.1029/2009GL041841, 2010.

Livingston, G. P. and Hutchinson, G. L.: Enclosure-based measurement of trace gas exchange: applications and sources of error, in: Biogenic Trace Gases: Measuring Emissions from Soil and Water, edited by: Matson, P., and Harriss, R., Blackwell Science, Cambridge, 14-50, 1995.

Misson, L., Limousin, J. M., Rodriguez, R., and Letts, M. G.: Leaf physiological responses to extreme droughts in Mediterranean Quercus ilex forest, Plant Cell Environ., 33 1898-1910, 2010.

O'Brien, S. L., Jastrow, J. D., Grimley, D. A., and Gonzalez-Meler, M. A.: Moisture and vegetation controls on decadal-scale accrual of soil organic carbon and total nitrogen in restored grasslands, Glob. Change Biol., 16, 2573-2588, doi:10.1111/j.13652486.2009.02114.x, 2010.

Raich, J. W. and Schlesinger, W. H.: The global carbon-dioxide flux in soil respiration and its relationship to vegetation and climate, Tellus B., 44, 81-99, 1992.
Reichstein, M., Tenhunen, J. D., Roupsard, O., Ourcival, J. M., Rambal, S., Miglietta, F., Peressotti, A., Pecchiari, M., Tirone, G., and Valentini, R.: Severe drought effects on ecosystem CO2 and $\mathrm{H} 2 \mathrm{O}$ fluxes at three Mediterranean evergreen sites: revision of current hypotheses?, Glob. Change Biol., 8, 999-1017, 2002.

Rey, A., Pegoraro, E., Tedeschi, V., De Parri, I., Jarvis, P. G., and Valentini, R.: Annual variation in soil respiration and its components in a coppice oak forest in Central Italy, Glob. Change Biol., 8, 851-866, 2002.

Ripullone, F., Borghetti, M., Raddi, S., Vicinelli, E., Baraldi, R., Guerrieri, M. R., Nole, A., and Magnani, F.: Physiological and structural changes in response to altered precipitation regimes in a Mediterranean macchia ecosystem, Trees-Struct. Funct., 23, 823-834, doi:10.1007/s00468-009-0323-2, 2009.

Sardans, J., Penuelas, J., and Ogaya, R.: Drought-induced changes in $\mathrm{C}$ and $\mathrm{N}$ stoichiometry in a Quercus ilex Mediterranean forest, Forest Science, 54, 513-522, 2008.

Saxton, K. E., Rawls, W. J., Romberger, J. S., and Papendick, R. I.: Estimating generalized soil-water characteristics from texture, Soil Sci. Soc. Am. J., 50, 1031-1036, 1986.

Schiermeier, Q.: The real holes in climate science Nature, 463, 284 287, doi:10.1038/463284a, 2010.

Subke, J. A., Inglima, I., and Cotrufo, M. F.: Trends and methodological impacts in soil $\mathrm{CO} 2$ efflux partitioning: A metaanalytical review, Glob. Change Biol., 12, 921-943, 2006.

Talmon, Y., Sternberg, M., and Grunzweig, J. M.: Impact of rainfall manipulations and biotic controls on soil respiration in Mediterranean and desert ecosystems along an aridity gradient, Glob. Change Biol., 17, 1108-1118, doi:10.1111/j.13652486.2010.02285.x, 2011.

Tang, J., Qi, Y., Xu, M., Misson, L., and Goldstein, A. H.: Forest thinning and soil respiration in a Ponderosa pine plantation in the Sierra Nevada, Tree Physiol., 25, 57-66, 2005.

Tedeschi, V., Rey, A., Manca, G., Valentini, R., Jarvis, P. G., and Borghetti, M.: Soil respiration in a Mediterranean oak forest at different developmental stages after coppicing, Glob. Change Biol., 12, 110-121, 2006.

Tipping, E., Woof, C., Rigg, E., Harrison, A. F., Ineson, P., Taylor, K., Benham, D., Poskitt, J., Rowland, A. P., Bol, R., and Harkness, D. D.: Climatic influences on the leaching of dissolved organic matter from upland UK Moorland soils, investigated by a field manipulation experiment, Environ. Int., 25, 83-95, 1999.

Zhao, M. S. and Running, S. W.: Drought-Induced Reduction in Global Terrestrial Net Primary Production from 2000 through 2009, Science, 329, 940-943, 2010. 